\title{
Efficiency of Arsenic and Iron Removal Plants (AIRPs) for Groundwater Treatment in Rural Areas of Southwest Bangladesh
}

\author{
Md. Aminur Rahman 1,2,*(D), Sazal Kumar ${ }^{3,4} \mathbb{D}^{D}$, A. S. M. Fazle Bari ${ }^{1,5}$, Abhishek Sharma 1 \\ and Mohammad Mahmudur Rahman 1,*D \\ 1 Global Centre for Environmental Remediation (GCER), The University of Newcastle, \\ Callaghan, NSW 2308, Australia; a.s.m.fazle.bari@uon.edu.au (A.S.M.F.B.); \\ abhishek.sharma@newcastle.edu.au (A.S.) \\ 2 Zonal Laboratory, Department of Public Health Engineering (DPHE), Khulna 9100, Bangladesh \\ 3 Key Laboratory of Ocean and Marginal Sea Geology, South China Sea Institute of Oceanology, \\ Innovation Academy of South China Sea Ecology and Environmental Engineering, Chinese Academy of \\ Sciences, Guangzhou 510301, China; sazalkumar.iu@gmail.com \\ 4 University of Chinese Academy of Sciences, Beijing 100049, China \\ 5 Department of Soil Science, Sher-e-Bangla Agricultural University, Dhaka 1207, Bangladesh \\ * Correspondence: md.aminur.rahman@uon.edu.au (M.A.R.); mahmud.rahman@newcastle.edu.au (M.M.R.)
}

Citation: Rahman, M.A.; Kumar, S.; Bari, A.S.M.F.; Sharma, A.; Rahman, M.M. Efficiency of Arsenic and Iron Removal Plants (AIRPs) for Groundwater Treatment in Rural Areas of Southwest Bangladesh. Water 2021, 13, 354. https://doi.org/ 10.3390/w13030354

Academic Editors:

Andreas N. Angelakis

Received: 15 December 2020

Accepted: 27 January 2021

Published: 30 January 2021

Publisher's Note: MDPI stays neutral with regard to jurisdictional claims in published maps and institutional affiliations.

Copyright: (c) 2021 by the authors. Licensee MDPI, Basel, Switzerland. This article is an open access article distributed under the terms and conditions of the Creative Commons Attribution (CC BY) license (https:/ / creativecommons.org/licenses/by/ $4.0 /)$.

\begin{abstract}
Arsenic (As) removal plants were installed in As-endemic areas of Bangladesh to remove As from well water. In many cases, these removal plants did not perform satisfactorily. This study evaluated the efficiency of 20 As and iron (Fe) removal plants (AIRPs) during pre- and post-monsoon conditions in rural Bangladesh. Results revealed that As removal efficiencies ranged from $67 \%$ to $98 \%$ and 74 to $93 \%$ during the pre- and post-monsoons periods, respectively. In the post-monsoon season As removal at individual AIRP sites was on average (4.01\%) greater than in the pre-monsoon season. However, two removal plants were unable to remove As below $50 \mu \mathrm{g} \mathrm{L}^{-1}$ (Bangladesh drinking water standard) during pre-monsoon, while 11 samples out of 20 were unable to remove As below the WHO provisional guideline value of $10 \mu \mathrm{g} \mathrm{L}^{-1}$. During post-monsoon, none of the samples exceeded $50 \mu \mathrm{g} \mathrm{L}^{-1}$, but eight of them exceeded $10 \mu \mathrm{g} \mathrm{L}^{-1}$. The Fe removal efficiencies of AIRPs were evident in more than $80 \%$ samples. Although As removal efficiency was found to be substantial, a cancer risk assessment indicates that hazard quotient $(\mathrm{HQ})$ and carcinogenic risk (CR) of As in treated water for adults and children are above the threshold limits. Thus, additional reductions of As concentrations in treated water are needed to further reduce the excess cancer risk due to As in drinking water. Since $55 \%$ and $40 \%$ of the AIRPs were unable to remove As $<10 \mu \mathrm{g} \mathrm{L}^{-1}$ during pre-monsoon and post-monsoon, further improvement including changes in AIRP design, regular cleaning of sludge, and periodic monitoring of water quality are suggested. Future research is needed to determine whether these modifications improve the performance of AIRPs.
\end{abstract}

Keywords: arsenic; iron; groundwater; low-cost technology; water treatment

\section{Introduction}

Arsenic (As) is a known human carcinogen and elevated concentrations of As have been detected in the groundwater (which is used for drinking) in many parts of the world [1-3]. However, countries located in the Southeast Asian region are the worst affected [4]. The concentration of As in groundwater is known to reach very high levels (e.g., up to $5 \mathrm{mg} \mathrm{L}^{-1}$ ) in Bangladesh, India, Vietnam, Pakistan, Nepal, Chile, Taiwan, and China [5-8]. In Bangladesh about 32 million people are exposed to As-contaminated water and many people are suffering from As-related diseases including cancers of different organs. This is due to the chronic consumption of contaminated As-water [5,9]. 
The presence of iron $(\mathrm{Fe})$ in waters resulting from weathering of rocks and minerals as well as by rainwater while percolating through soils acquires Fe in addition to other mineral constituents. Iron may also contribute to groundwater by its contact with the casing, pump assemblies, pipes, and storage tanks [10]. A high concentration of Fe can cause vomiting, diarrhea, with subsequent damage being done to the cardiovascular and central nervous systems, including liver, kidneys, and blood [11]. The World Health Organization (WHO) [12] has not established a guideline limit of Fe in water, but the Bangladesh government has set the limit at $1000 \mu \mathrm{g} \mathrm{L}{ }^{-1}$ [13].

The Bangladesh government with the aid of various donor agencies utilizes multiple mitigation strategies to reduce people's exposure to As from groundwater. One option is to remove and/or reduce As from contaminated wells using available As removal plants. Various remediation technologies are currently used for the removal of As including oxidation, sand filtration, ion exchange, adsorption, chemical precipitation, activated alumina, reverse osmosis, membrane filtration, coagulation/filtration, and enhanced lime softening [14-19]. However, these technologies are still not suitable for large-scale remediation efforts and only validated so far in the laboratory; they are expensive as well [20-22]. Therefore, it requires elementary, cost-efficient, and flexible technology that can resolve the current problem.

An arsenic and iron removal plant (AIRP) is a simple and efficient technology that can remove both As and Fe on a larger scale, and the production cost of this technology is around USD 3000 [23]. The Department of Public Health and Engineering (DPHE) installed the AIRPs during July 2015 with the aid of the Secondary Education Quality and Access Enhancement Project (SEQAEP). The model of an AIRP is shown in Figure 1. The AIRP is a simple unit comprising two tanks that function on the principle of oxidation and coprecipitation. The larger aeration tank and a small filtration tank contain coarse sand, charcoal, and brick chip media [24].

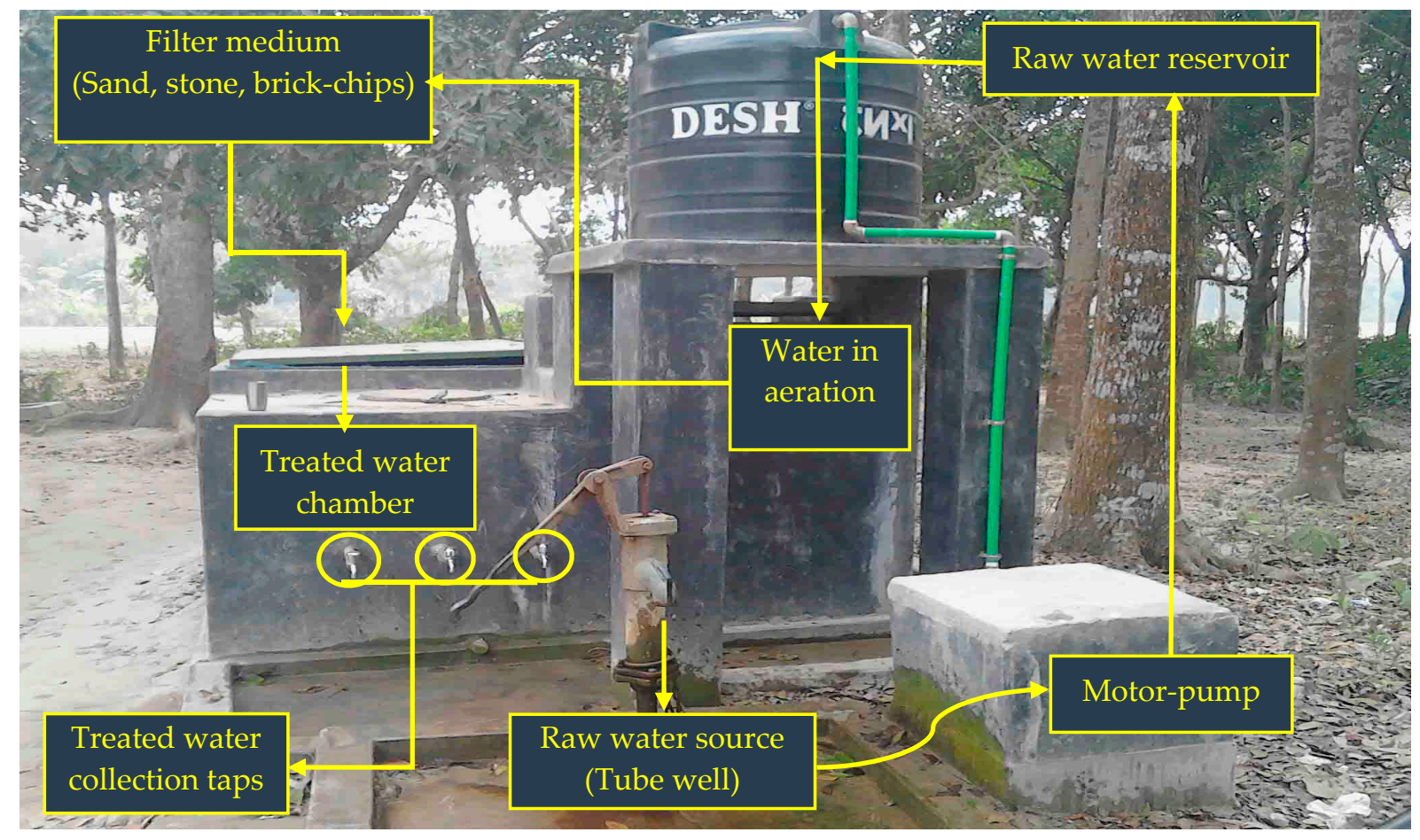

Figure 1. A schematic diagram of AIRP in the rural area of Jashore district in southwest Bangladesh.

Several investigations revealed that naturally occurring Fe plays a crucial role in the removal of As $[25,26]$. A study reported that groundwater containing iron Fe (II) levels $\left(2.33 \pm 0.03 \mathrm{mg} \mathrm{L}^{-1}\right)$ adsorbed $91 \%$ As in anoxic conditions compared to $61 \%$ of As in oxic 
conditions [14]. However, Holm and Wilson [27] found that the As removal rate was only $20-25 \%$ in the presence of naturally available Fe $\left(>1.5 \mathrm{mg} \mathrm{L}^{-1}\right)$. In a study of As removal using multiple or continuous Fe addition, Roberts, et al. [28] observed that $>80 \mathrm{mg} \mathrm{L}^{-1}$ $\mathrm{Fe}(\mathrm{III}), 50-55 \mathrm{mg} \mathrm{L}^{-1} \mathrm{Fe}(\mathrm{II})$ in one single addition, and $20-25 \mathrm{mg} \mathrm{L}^{-1}$ in multiple additions are required to remove $500 \mu \mathrm{g} \mathrm{L}^{-1}$ of As(III) to below $50 \mu \mathrm{g} \mathrm{L} \mathrm{L}^{-1}$ As. In case of As(V), 10-12 $\mathrm{mg} \mathrm{L}^{-1} \mathrm{Fe}(\mathrm{II})$ and $15-18 \mathrm{mg} \mathrm{L}^{-1} \mathrm{Fe}(\mathrm{III})$ were also required [28]. Additionally, the molar ratio of $\mathrm{Fe} / \mathrm{As}$ in groundwater is a critical factor and usually varies in aquifer settings and local conditions. For example, the average molar ratio of Fe/As in Nepal's groundwater was reported as 9.4 in post-monsoon and 6.0 in pre-monsoon [29] whereas average molar Fe/As ratio in Vietnam's groundwater was between 60 and 68 [30].

In As-endemic areas of Bangladesh, two studies reported very different molar $\mathrm{Fe} / \mathrm{As}$ ratios of 15 and 90 [31,32]. Generally, Fe content in groundwater is elevated and this plays an important role in the removal of As from contaminated groundwater [15]. In a study from Vietnam using sand filtration for the removal of As, it was reported that the filtering system can reduce the As levels below $10 \mu \mathrm{g} \mathrm{L}^{-1}$ when the ratio of Fe/As was $\geq 250$ [15]. The sand filter can remove As below $50 \mu \mathrm{g} \mathrm{L}^{-1}$ when the ratio of Fe/As was $\geq 50$ [15]. For this reason, it is crucial to investigate the role of $\mathrm{Fe} / \mathrm{As}$ ratio in the removal efficiencies of AIRPs in rural Bangladesh.

Numerous studies investigated the seasonal or temporal variation of As in groundwater especially in the alluvial and deltaic regions of the Bengal Delta [33-35]. Some reports showed that As contents increased with age of the wells or time while other analyses discounted claims of seasonal variations in As levels in groundwater [4]. Although it is important to investigate the removal efficiency due to interseasonal variability, the monitoring should be conducted over extended periods of time [36-38]. Two studies done in the Bengal Delta showed that As concentrations in groundwater of post-monsoon season were lower than pre-monsoon due to the impact of groundwater replenishment and dilution effect during the monsoon period $[29,39]$. Since the seasonal variation has major implications for mitigation efforts, we also investigated whether interseason variation wields any influence on AIRPs' efficiency in removing As and Fe.

Based on a 2-year efficiency study on 18 AIRPs from As-affected areas of West Bengal [40], it was reported that, firstly, none of the AIRPs could maintain As in treated water below the WHO provisional guideline value $\left(10 \mu \mathrm{g} \mathrm{L}^{-1}\right)$; and secondly, only two could meet the previous Indian standard value $\left(50 \mu \mathrm{g} \mathrm{L}^{-1}\right)$. Studies on evaluating the removal efficiencies of As and Fe by AIRPs installed for practical use in rural Bangladesh are very limited. For example, Brennan and McBean [10] evaluated the performance of 21 installed AIRPs in the Manikgong district in Bangladesh. They observed that all of the AIRPs achieved the Bangladesh drinking water standard for As $\left(50 \mu \mathrm{g} \mathrm{L}^{-1}\right)$, but four of them failed to reach the WHO provisional guideline value of As $\left(10 \mu \mathrm{g} \mathrm{L}^{-1}\right)$; on average the removal efficiency was $87 \%$ [10]. In another more recent study, Sorensen, et al. [41] studied the performance enhancement of the AIRPs, indicating that the addition of iron scarp and raising the pipe intake can enhance efficiency by $13 \%$ and $3 \%$, respectively. Although the initial performance of AIRPs is satisfactory, Sorensen and McBean [24] found that the efficiency of AIRPs declined by $10 \% 3$ years after installation due to discontinued use and maintenance difficulties in the rural areas of Bangladesh. Previous studies did not consider the interseasonal variation, the role of Fe/As ratio on the performance of AIRPs, and the impacts of AIRP treatment on health risk assessment. Therefore, this study set out to evaluate: (i) the performance of 20 AIRPs in removing As and Fe during pre-monsoon (May 2019) and post-monsoon (November 2019) and factors influencing the removal efficiencies; (ii) the role of $\mathrm{Fe} / \mathrm{As}$ ratio in removal efficiencies; (iii) the impacts of AIRP treatment on health risk assessment in Jashore district's rural areas in southwest Bangladesh. 


\section{Materials and Methods}

\subsection{Sampling of Raw and AIRP Treated Waters}

Water samples were collected from wells where AIRPs (around 300-500 people use treated water from one AIRP) were installed to remove As from drinking water. Samples were taken from two unions (the second smallest administrative unit), namely Ganganandapur and Magura in Jhikargachha Upazila (sub-district), Jashore district, Bangladesh during May 2019 (pre-monsoon) and November 2019 (post-monsoon). Of the 31 AIRPs that are in use in Ganganandapur and Magura, 20 were selected at random for this study. The locations of the sampling points are presented in Figure 2.

Four samples (raw water and treated water during pre-monsoon and post-monsoon) were collected from each AIRP site in the high-density polyethylene (HDPE) bottles prewashed with 1:1 nitric acid for As and Fe estimation followed by acidified with nitric acid (1:1). The samples collected from Ganganandapur union were identified as G1 to G10, and those from Magura union were identified as M1 to M10.

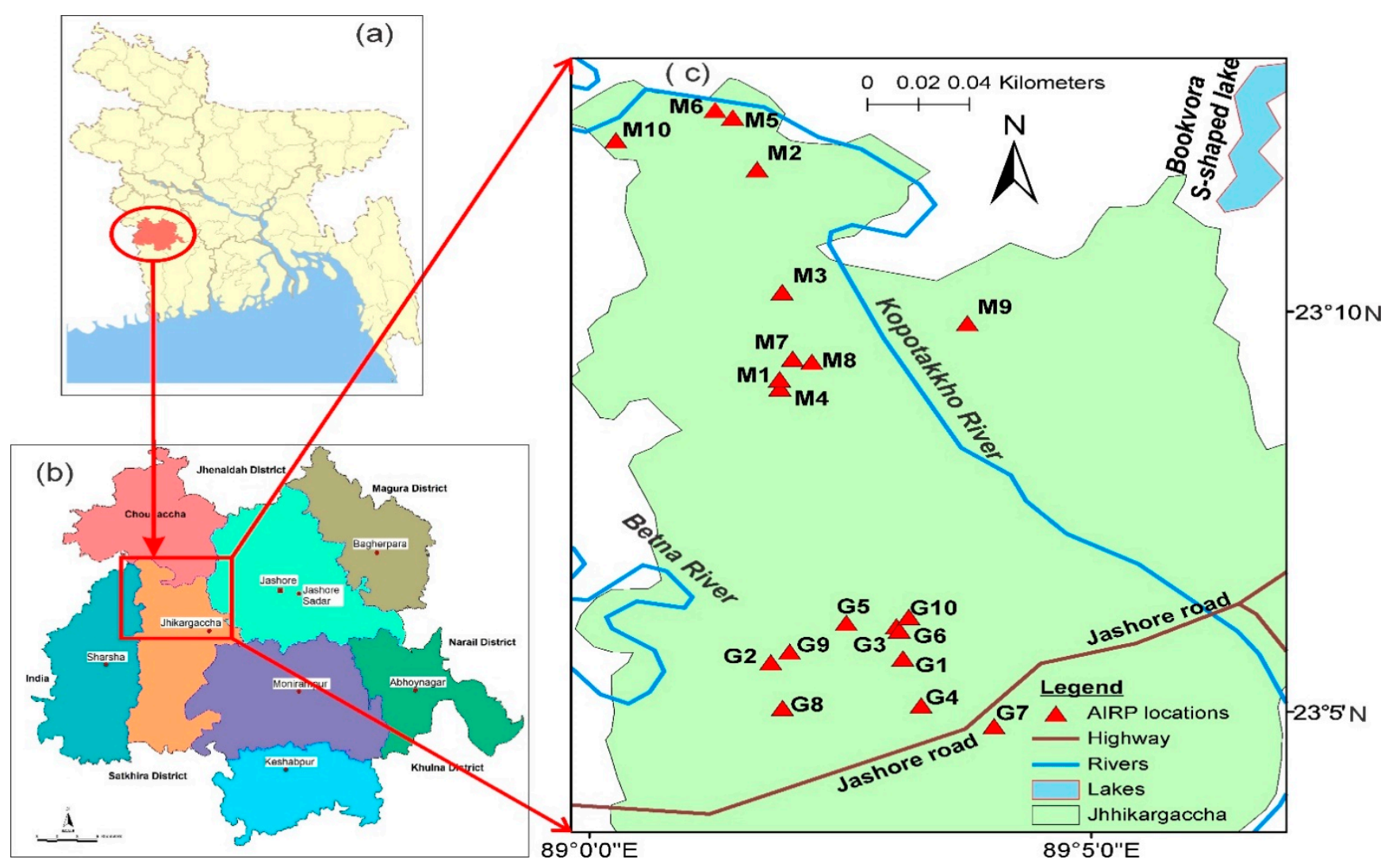

Figure 2. Study area map. (a) Location of Jashore district in Bangladesh; (b) Jashore district; (c) sampling location in Ganganandapur (indicated by " $\mathrm{G}$ ") and Magura (indicated by " $\mathrm{M}^{\prime}$ ) in Jashore district.

\subsection{Analysis of As and Fe}

Concentrations of As and Fe were analyzed by Atomic Absorption Spectrometry (AAS) method [42] (AAS Model: SpectrAA 220, Varian, Belrose, Australia). Details of the instrument were provided in our previously published article [43]. Briefly, As was measured by the hydride generation (HG-AAS) method utilizing a T-shaped quartz absorption cell VGA 76/77 (Varian). The argon served as a carrier gas (gas flow rate was $0.1 \mathrm{~L} / \mathrm{min}$ ) at the wavelength of $193.7 \mathrm{~nm}$ and slit width of $0.5 \mathrm{~nm}$. The reductant agent was sodium borohydride $\left(\mathrm{NaBH}_{4}-0.6 \% w / v\right)$ and the acid reagent was $\mathrm{HCl}(5 \mathrm{M})$. The Fe content was measured by direct flame (F-AAS) using air-acetylene (flow rate of air and acetylene was 13.5 and $2.0 \mathrm{~L} / \mathrm{min}$, respectively) at the wavelength of $248.3 \mathrm{~nm}$ and slit width of $0.2 \mathrm{~nm}$. A 
hollow cathode lamp was used as a light source selecting 10 and $5 \mathrm{~mA}$ lamp current for As and Fe measurements, respectively, and a deuterium lamp for background correction positioning the burner height at $13.5 \mathrm{~mm}$. Mean and standard deviations were calculated from the results of the analysis of the three samples per sampling point. Three times the standard deviation of the blank samples was used for determining the limit of detections (LOD) for both As and Fe. The LODs of As and Fe were observed to be 0.5 and $8 \mu \mathrm{g} / \mathrm{L}$, correspondingly, which seems to be good enough to measure the lower level of As and Fe of the aqueous solutions.

\subsection{Efficiency Calculation}

The removal efficiencies of As and Fe by AIRPs were estimated based on the initial concentrations of As and Fe in raw water by using the following formula.

$$
\text { Removal efficiency }(\%)=\left(\left(C_{i}-C_{f}\right) \times 100\right) / C_{i}
$$

where, $C_{i}$ and $C_{f}$ are the concentrations of trace As or Fe in raw and treated water, respectively.

\subsection{Human Health Risk Assessment}

The extent of risks both for adults and children were calculated in terms of hazard quotient (HQ) and carcinogenic risk (CR) for As in raw water and treated water during premonsoon and post-monsoon periods. The HQ and CR were calculated using the following equations [43,44]:

$$
\begin{gathered}
\mathrm{HQ}=\left(\mathrm{C} \times \mathrm{IR}_{\text {water }}\right) /\left(\mathrm{B}_{\text {weight }} \times \mathrm{RfDo}\right) \\
\mathrm{CR}=\left(\mathrm{C} \times \mathrm{IR}_{\text {water }} \times \mathrm{SF}\right) / \mathrm{B}_{\text {weight }}
\end{gathered}
$$

where $\mathrm{C}$ is the concentration of As and Fe in water $\left(\mu \mathrm{g} \mathrm{L}{ }^{-1}\right), \mathrm{IR}_{\mathrm{water}}$ is the ingestion rate of water (3.0 and $2.1 \mathrm{~L} \mathrm{day}^{-1}$ for adults and children, respectively) [45], $\mathrm{B}_{\text {weight }}$ is the body weight (60 and $16 \mathrm{~kg}$ for adults and children, respectively) (HIES 2011), RfDo is the oral reference dose ( 0.3 and $700 \mu \mathrm{g} \mathrm{kg}^{-1} \mathrm{day}^{-1}$ for As and Fe, respectively), and SF is the oral slope factor $\left(0.0015\left(\mu \mathrm{g} \mathrm{kg}{ }^{-1} \mathrm{day}^{-1}\right)^{-1}\right)$ [46]. Both HQ and CR were calculated for As and $\mathrm{HQ}$ was calculated for Fe only since currently there is no SF value for Fe.

\subsection{Statistical Analysis}

To determine the differences in As and Fe removal efficiencies and correlations among As removal efficiencies and $\mathrm{Fe}$ to $\mathrm{As}(\mathrm{Fe} / \mathrm{As}$ ) ratio during pre-monsoon and post-monsoon, $t$-test and Pearson's correlation ( $p$-value $<0.05$ was chosen to indicate statistical significance) were conducted. In addition, principal component analysis (PCA) was performed using $\mathrm{R}$ 3.4.3 software to determine the degree of correlation among As and Fe removal efficiencies and $\mathrm{Fe}$ to As ratios in raw and treated water during pre-monsoon and post-monsoon. Most of the variables were normally distributed as revealed by the Shapiro-Wilk test, leading to Pearson's correlation analysis of the data. The Kaiser-Meyer-Olkin (KMO) measure of sampling adequacy indicated a value of 0.585 , which is larger than 0.50 . Therefore, PCA was performed to ascertain correlations among the variables.

\section{Results and Discussion}

\subsection{Concentrations of As and Fe in Raw and Treated Water}

The concentrations of As and Fe in raw and treated water by 20 AIRPs during premonsoon and post-monsoon in rural areas of Jashore district are presented in Table S1 (Supplementary Information). The summary descriptive statistics of As and Fe in raw and treated water by AIRPs during pre-monsoon and post-monsoon are listed in Table 1. It should be noted that AIRP was installed in some wells where the concentration of As was below the Bangladesh drinking water standard $\left(50 \mu \mathrm{g} \mathrm{L}^{-1}\right)$. This is because the AIRP installation decision was taken based on the observed field kit test results, which may have shown an error due to the qualitative nature of field kits. It indicates that As concentrations 
in raw water during pre-monsoon ranged from 11 to $218 \mu \mathrm{g} \mathrm{L}^{-1}$ (mean: $95.7 \mu \mathrm{g} \mathrm{L}^{-1}$ ), which is about double and 10 times larger than the Bangladesh standard and WHO provisional guideline value of As in drinking water, respectively (Table 1).

The range of As content in raw water from Manikganj district, previously found to be reported, ranged from 1 to $232 \mu \mathrm{g} \mathrm{L}^{-1}$ [10]. In contrast to Jashore district, raw water for As removal plants (ARPs) from West Bengal, India contained a mean As content of $185 \mu \mathrm{g} \mathrm{L}^{-1}$ [40], which is about twice that of this study. Conversely, after treatment with AIRP, the concentration of As diminished to the 1-64 $\mu \mathrm{g} \mathrm{L}^{-1}$ range (mean: $20.3 \mu \mathrm{g} \mathrm{L}^{-1}$ ) (Table 1), which is double that of the WHO provisional guideline value. However, it is much lower than the Bangladesh drinking water standard. However, specifically, after treatment with the AIRPs, only two samples (M-1 and M-8) exceeded the Bangladesh drinking water standard of $50 \mu \mathrm{g} \mathrm{L}^{-1}$ and 11 samples (55\%) out of 20 surpassed the WHO provisional guideline value of $10 \mu \mathrm{g} \mathrm{L}^{-1}$ (Figure 3). Hossain et al. [40] also reported that about $53.1 \%$ ARP treated water (140 out of 264 ) in West Bengal, India failed to maintain the provisional guideline value of $10 \mu \mathrm{g} \mathrm{L}^{-1}$ and $27.7 \%$ (73 out of 264) failed to maintain the standard value of $50 \mu \mathrm{g} \mathrm{L}^{-1}$. Since some of the AIRPs failed to remove As below the provisional guideline value of $\mathrm{WHO}$ and people are drinking treated water, it is very evident that the health risk cannot be neglected.

During post-monsoon, the As concentration in the raw water ranged from 15 to $186 \mu \mathrm{g} \mathrm{L}^{-1}$ (mean: $78.9 \mu \mathrm{g} \mathrm{L}^{-1}$ ), whereas after treatment with AIRP, the concentration dropped to the 1-45 $\mu \mathrm{g} \mathrm{L}^{-1}$ range (mean: $13.2 \mu \mathrm{g} \mathrm{L}^{-1}$ ) (Table 1). However, after treatment, none of the samples exceeded the drinking standard of Bangladesh, but eight (40\%) exceeded the provisional guideline limit of WHO (Figure 3). The concentration of As in raw water during post-monsoon is lower than the pre-monsoon (mean: $95.7 \mu \mathrm{g} \mathrm{L}^{-1}$, range: $11-218 \mu \mathrm{g} \mathrm{L}^{-1}$ ) because plenty of groundwater is accessible during the monsoon and post-monsoon phases. This is due to heavy rainfall helping to reduce the concentration of As in groundwater [47].

During pre-monsoon, the concentration of Fe in the raw water ranged between 1230 and $3770 \mu \mathrm{g} \mathrm{L}^{-1}$ (mean: $2698 \mu \mathrm{g} \mathrm{L}{ }^{-1}$ ), however, after treatment with AIRP the concentration reduced to a value ranging between 120 and $920 \mu \mathrm{g} \mathrm{L}^{-1}$ (mean: $460 \mu \mathrm{g} \mathrm{L}^{-1}$ ) (Table 1). In raw water from Manikganj district, Fe content varied from 5400 to $24,400 \mu \mathrm{g} \mathrm{L}{ }^{-1}$ [10], which was much higher than what this study documented. Currently, there is no WHO guideline limit for Fe, but the Bangladesh drinking water standard is $1000 \mu \mathrm{g} \mathrm{L}^{-1}$ [13]. After treatment with AIRP, all water samples were below the Bangladesh drinking water standard of $\mathrm{Fe}$, although the concentration of $\mathrm{Fe}$ in a sample was $920 \mu \mathrm{g} \mathrm{L}^{-1}$, which is slightly lower than the Bangladesh drinking water standard (Figure 4).

In contrast, during post-monsoon, the concentration of $\mathrm{Fe}$ in raw and treated water ranged between 750-5350 $\mu \mathrm{g} \mathrm{L}^{-1}$ (mean $2473 \mu \mathrm{g} \mathrm{L}^{-1}$ ) and 100-670 $\mu \mathrm{g} \mathrm{L}^{-1}$ (mean: $347.5 \mu \mathrm{g} \mathrm{L}^{-1}$ ), respectively (Table 1). In the treated water, the Fe concentration was much lower than the Bangladesh drinking water standard limit, and none of the samples surpassed the standard limit (Figure 4). A recent study from Jashore district reported Fe content in raw groundwater was found to be in the 20-6200 $\mu \mathrm{g} \mathrm{L}^{-1}$ range [48]. About $28 \%$ samples had a mean Fe concentration of $3720 \mu \mathrm{g} \mathrm{L}^{-1}$ [48], which is 1.4 and 1.5 times higher than Fe content in raw water in pre-monsoon and post-monsoon, respectively, in this study (Table 1). The mean content of Fe in raw water was reported as $4493 \mu \mathrm{g} \mathrm{L}^{-1}$ in West Bengal of India [40], which was about twice as big as that in this study (Table 1). In addition, ARP treated water had an average Fe content of $2630 \mu \mathrm{g} \mathrm{L}^{-1}$ [40], which is about six and eight times higher than reported for preand post-monsoon in this study. 
Table 1. The summary descriptive statistics of As and $\mathrm{Fe}\left(\mu \mathrm{g} \mathrm{L}^{-1}\right)$ in raw water and treated water by AIRP from rural areas in Bangladesh.

\begin{tabular}{|c|c|c|c|c|c|c|c|c|c|c|c|c|c|c|c|c|}
\hline \multirow{4}{*}{ Parameters } & \multicolumn{4}{|c|}{$\begin{array}{l}\text { Pre-Monsoon (May 2019) } \\
\qquad(n=20)\end{array}$} & \multicolumn{4}{|c|}{$\begin{array}{l}\text { Post-Monsoon (November 2019) } \\
\qquad(n=20)\end{array}$} & \multicolumn{8}{|c|}{ Pairwise $t$-Test } \\
\hline & \multirow{2}{*}{\multicolumn{2}{|c|}{$\begin{array}{c}\text { Raw Water } \\
(n=20)\end{array}$}} & \multirow{2}{*}{\multicolumn{2}{|c|}{$\begin{array}{c}\text { Treated Water } \\
\quad(n=20)\end{array}$}} & \multirow{2}{*}{\multicolumn{2}{|c|}{$\begin{array}{l}\text { Raw Water } \\
\quad(n=20)\end{array}$}} & \multirow{2}{*}{\multicolumn{2}{|c|}{$\begin{array}{l}\text { Treated Water } \\
\quad(n=20)\end{array}$}} & \multirow{2}{*}{\multicolumn{2}{|c|}{$\begin{array}{c}\begin{array}{c}\text { Raw Water } \\
(n=20)\end{array} \\
\begin{array}{c}\text { Pre-Monsoon vs. } \\
\text { Post-Monsoon }\end{array}\end{array}$}} & \multirow{2}{*}{\multicolumn{2}{|c|}{$\begin{array}{l}\begin{array}{c}\text { Treated Water } \\
(n=20)\end{array} \\
\begin{array}{c}\text { Pre-Monsoon vs. } \\
\text { Post-Monsoon }\end{array}\end{array}$}} & \multirow{2}{*}{\multicolumn{2}{|c|}{ 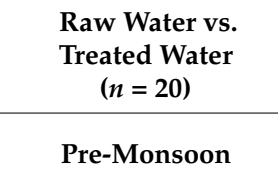 }} & \multirow{2}{*}{\multicolumn{2}{|c|}{ 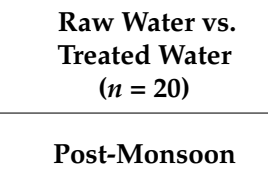 }} \\
\hline & & & & & & & & & & & & & & & & \\
\hline & As & $\mathrm{Fe}$ & As & $\mathrm{Fe}$ & As & $\mathrm{Fe}$ & As & $\mathrm{Fe}$ & As & $\mathrm{Fe}$ & As & $\mathrm{Fe}$ & As & $\mathrm{Fe}$ & As & $\mathrm{Fe}$ \\
\hline \multirow{3}{*}{$\begin{array}{l}\text { Mean } \\
\text { Median } \\
\text { Standard } \\
\text { deviation } \\
\text { Range }\end{array}$} & 95.7 & 2698 & 20.3 & 460 & 78.9 & 2473 & 13.25 & 347.5 & \multirow{3}{*}{0.074} & \multirow{3}{*}{0.298} & \multirow{3}{*}{$0.036 *$} & \multirow{3}{*}{0.051} & \multirow{3}{*}{$<0.01^{* *}$} & \multirow{3}{*}{$<0.01$ ** } & \multirow{3}{*}{$<0.01$ ** } & \multirow{3}{*}{$<0.01 *$} \\
\hline & 60.4 & 665 & 18.88 & 193 & 46.3 & 1098 & 12.94 & 153 & & & & & & & & \\
\hline & $11-218$ & $1230-3770$ & $1-64$ & $120-920$ & $15-186$ & $750-5350$ & $1-45$ & $100-670$ & & & & & & & & \\
\hline
\end{tabular}




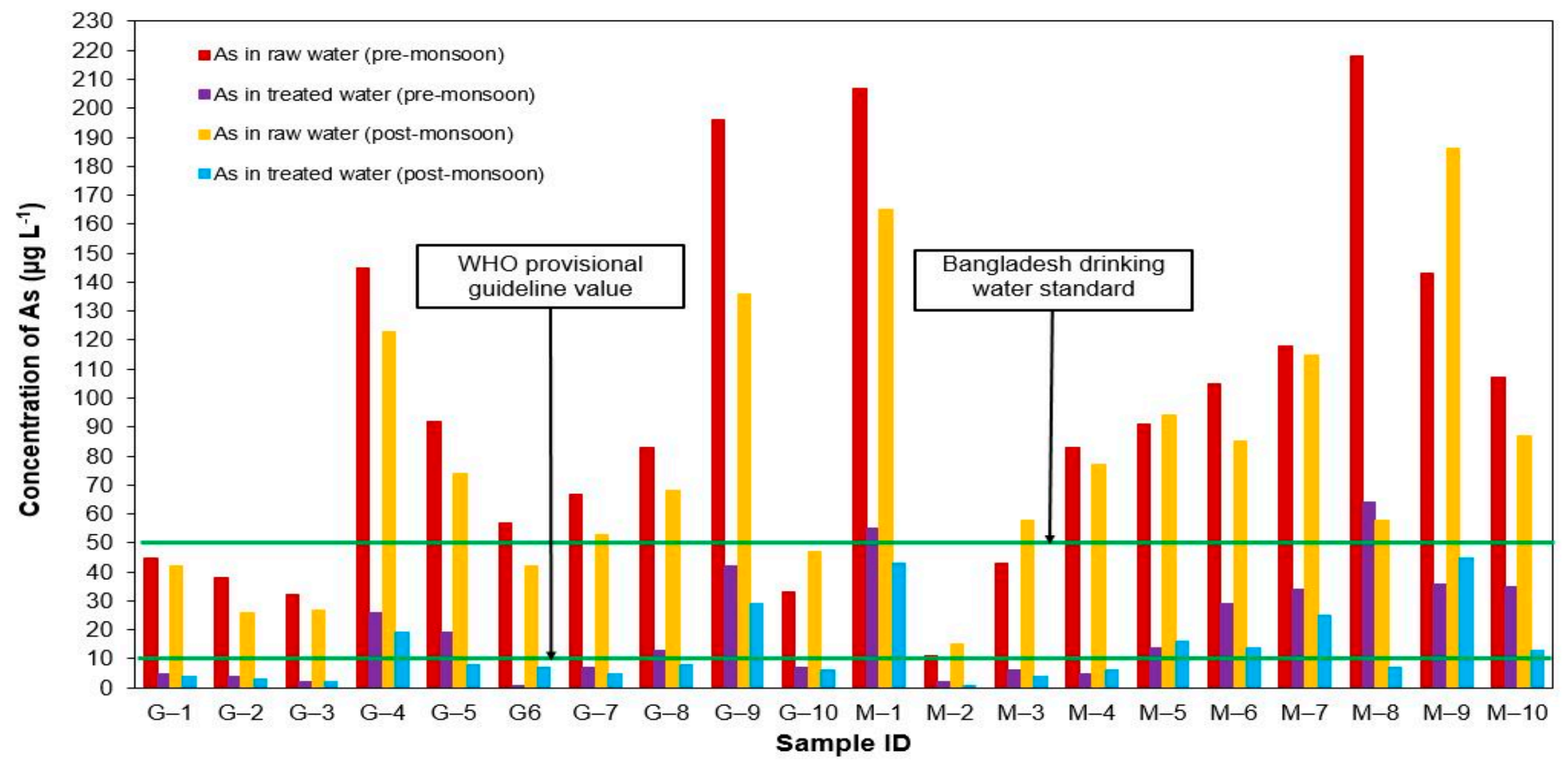

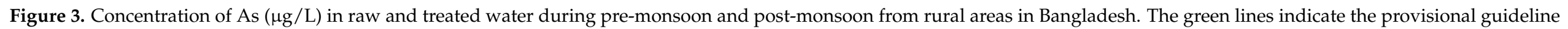
value of WHO and standard limit of Bangladesh. 


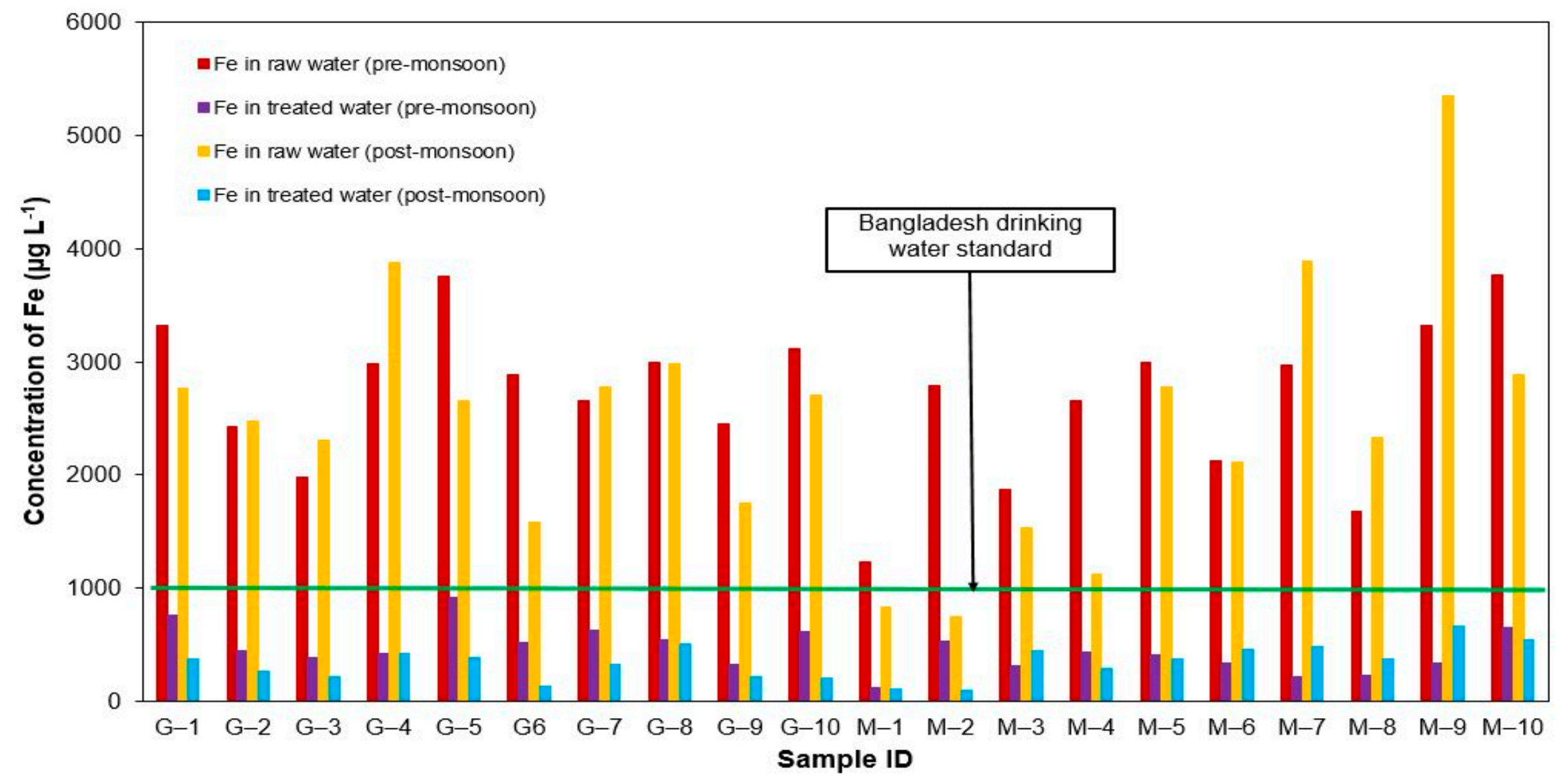

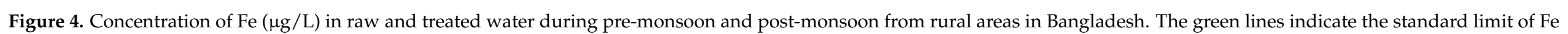
in Bangladesh. 
Overall, concentrations of As and Fe in pre-monsoon were higher than post-monsoon both in raw and treated water. This smaller concentration in post-monsoon could be due to the heavy rainfall during the monsoon and post-monsoon period in Bangladesh, which helps to dilute the concentrations of As and Fe in groundwater [47]. Pairwise $t$-test indicated that there was a statistically significant $(p=0.035)$ difference of As concentration in treated water (Table 1) between pre-monsoon and post-monsoon. When we compared between raw and treated waters, statistically significant differences of As and Fe were also found in both seasons (Table 1).

\subsection{Removal Efficiencies of As and Fe by AIRPs}

The efficiency of AIRPs in removing As is relatively better during post-monsoon than pre-monsoon. During post-monsoon, 16 (80\%) out of 20 AIRPs demonstrated a removal efficiency for As more than 80\%. Yet during pre-monsoon, 11 (55\%) AIRPs revealed a removal efficiency for As, amounting to more than $80 \%$. During pre-monsoon removal efficiencies ranged from $67 \%$ to $98 \%$, and during post-monsoon, it ranged between $74 \%$ and $93 \%$. In Manikganj, the As removal efficiencies of AIRPs were approximately 87\% [10], which was slightly higher than this study. However, a field study on 60 AIRPs throughout Bangladesh showed a removal efficiency between $50 \%$ and $90 \%$ and mostly operating in the range of $60-70 \%$ [49], which are slightly lower than this study. In that study, it was also observed that when As concentration was below $200 \mu \mathrm{g} \mathrm{L}^{-1}$ and Fe to As ratio is greater than 30 in raw water, the removal efficiency was over 75\% [49]. Similar findings were observed from community-level AIRPs in Bangladesh [50].

Conversely, Fe removal efficiencies were entirely satisfactory during both pre-monsoon and post-monsoon. The Fe removal efficiencies varied between $75-93 \%$ and $71-92 \%$ during pre-monsoon and post-monsoon, respectively, while most of them (17 out of 20) were operating with removal efficiencies amounting to more than $80 \%$. The Fe removal efficiencies are lower than the study on AIRPs in Manikganj, which discovered that Fe removal efficiencies ranged between $94 \%$ and $100 \%$ [10]. The paired difference in As removal efficiency in the post-monsoon vs. pre-monsoon was (4.01), which was statistically significant $(p=0.028)$.

Interestingly, in some cases, when As removal efficiencies were higher, Fe removal efficiencies were comparatively poorer. In general, As removal efficiency depends on the Fe and As concentrations in water. Therefore, Pearson's correlation analysis and PCA were performed to observe the extent of correlation among As and Fe removal efficiencies and $\mathrm{Fe} / \mathrm{As}$ ratio in raw and treated water during pre-monsoon and post-monsoon (see Figures 5 and 6). The results of the PCA are presented in Table 2. The correlation analysis revealed that there is a significant positive correlation $(\mathrm{r}=0.86 ; p=0.001)$ between As removal efficiency and $\mathrm{Fe} / \mathrm{As}$ ratio $(\mathrm{r}=0.83)$ in treated water during post-monsoon. In addition, a significant correlation $(\mathrm{r}=0.67 ; p=0.01)$ between Fe/As ratio in raw water (postmonsoon) and Fe/As ratio in treated water (post-monsoon) was observed. It indicates that the dependence of As removal efficiency on Fe/As ratio in raw and treated water during post-monsoon, is also confirmed by PCA. In PCA, As removal efficiency (pre-monsoon), $\mathrm{Fe} / \mathrm{As}$ ratio in raw water (post-monsoon), $\mathrm{Fe} / \mathrm{As}$ ratio in raw water (pre-monsoon), and $\mathrm{Fe} /$ As ratio in treated water (pre-monsoon) formed cluster-1 (Figure 6). Another significant positive correlation ( $\mathrm{r}=0.67 ; p=0.01$ ) was observed between As removal efficiency (premonsoon) and $\mathrm{Fe} / \mathrm{As}$ ratio in raw water (pre-monsoon) (Figure 5). In PCA, they also formed cluster-1, thus confirming their strong correlation (Figure 6). 


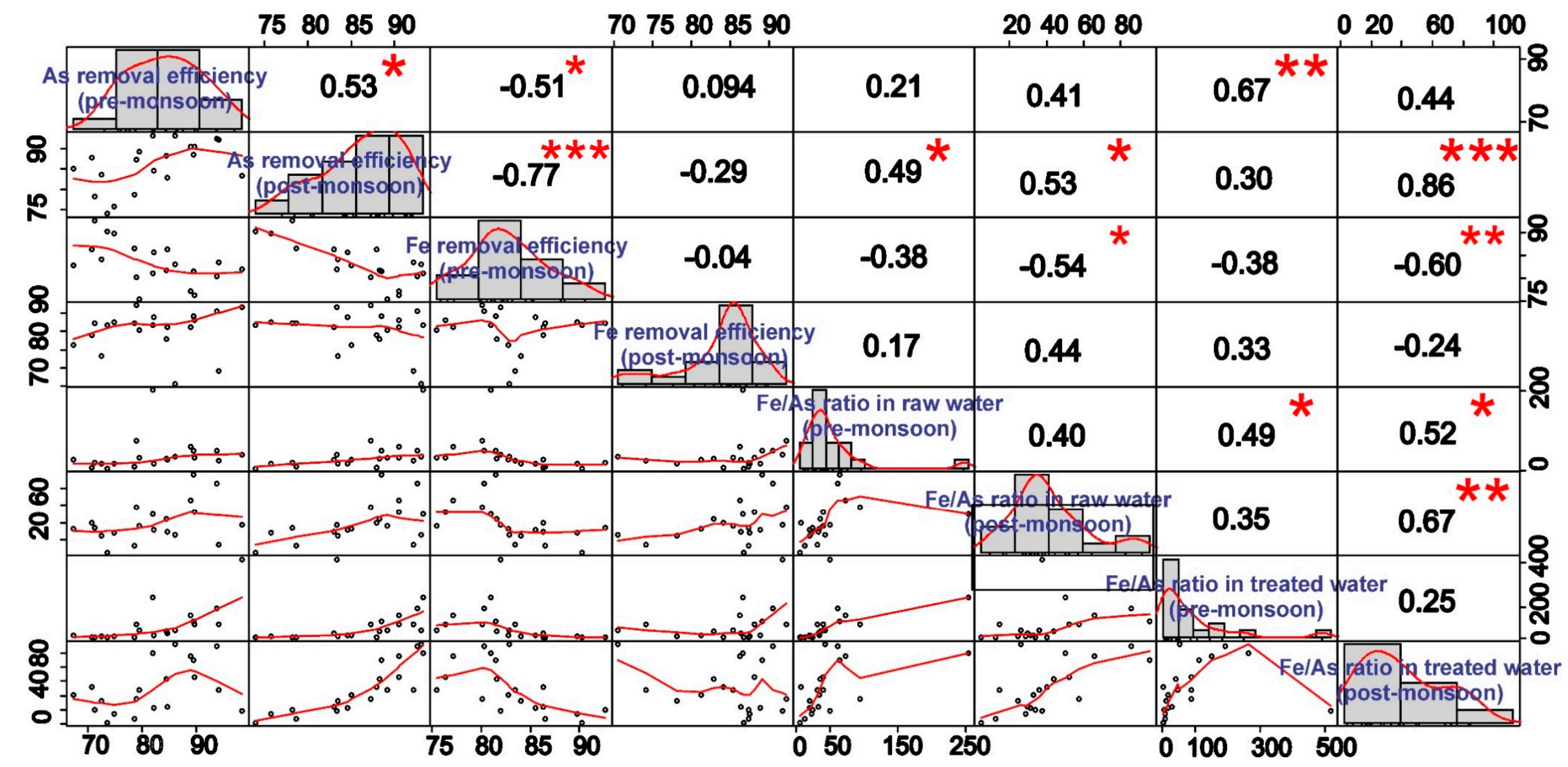

Figure 5. Pearson's correlation analysis ( ${ }^{*}$ correlation is significant at the 0.05 level; ${ }^{* *}$ correlation is significant at the 0.01 level; ${ }^{* * *}$ correlation is significant at the 0.001 level). 


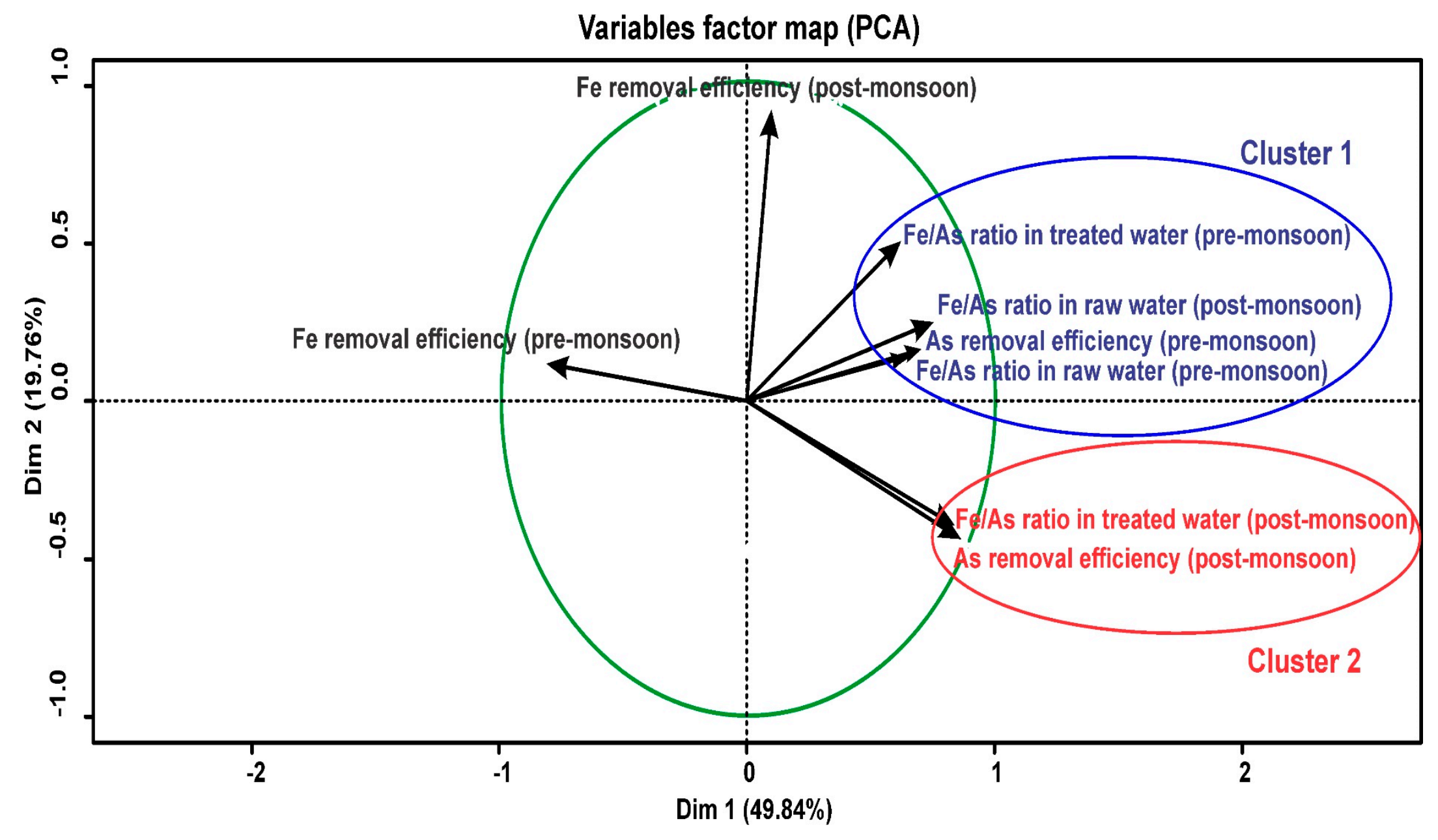

Figure 6. Component plot of principal component analysis. 
Table 2. Results of principal component analysis (PCA).

\begin{tabular}{ccc}
\hline Parameters & PC 1 (Dim 1) & PC 2 (Dim 2) \\
\hline As removal efficiency (pre-monsoon) & $\mathbf{0 . 7 0 4}$ & 0.166 \\
As Removal efficiency (post-monsoon) & $\mathbf{0 . 8 6 5}$ & -0.437 \\
Fe Removal efficiency (pre-monsoon) & -0.809 & 0.119 \\
Fe Removal efficiency (post-monsoon) & 0.098 & $\mathbf{0 . 9 2 3}$ \\
Fe/As in Raw Water (pre-monsoon) & 0.646 & 0.139 \\
Fe/As in Raw Water (post-monsoon) & $\mathbf{0 . 7 5 4}$ & 0.252 \\
Fe/As in Treated Water (pre-monsoon) & 0.624 & 0.508 \\
Fe/As in Treated Water (post-monsoon) & $\mathbf{0 . 8 3 9}$ & $-\mathbf{0 . 3 9 4}$ \\
Eigenvalues & 3.987 & 1.581 \\
Cumulative Eigenvalues & 3.987 & 5.568 \\
Percent of variance (\%) & 49.837 & 19.757
\end{tabular}

Note: The value in bold indicating dominant species.

Therefore, As removal efficiency depends on $\mathrm{Fe} / \mathrm{As}$ ratio in raw water. It was observed that more than $80 \%$ As was removed when $\mathrm{Fe} / \mathrm{As}$ ratio was more than 21 in raw water during pre-monsoon. It is noted that when $\mathrm{Fe} / \mathrm{As}$ ratio is $\geq 32$ and the As levels are between 50 and $100 \mu \mathrm{g} \mathrm{L}^{-1}$ in raw water, the concentration of As fell to below the WHO provisional guideline value in pre-monsoon (removal efficiency by AIRP was higher than $80 \%$ ). In post-monsoon, the $\mathrm{Fe} / \mathrm{As}$ ratio decreased to 26 (except in one sample M-4) for similar results i.e., removal efficiency was observed. (Table S2). It was reported that $\mathrm{Fe} / \mathrm{As}$ ratio of 30 was found to achieve $75 \%$ As removal efficiency in the community-based AIRPs in Bangladesh [50]. Apart from this, to achieve As removal efficiencies of $80-90 \%$, the United States Environmental Protection Agency recommends the Fe/As ratio of 20 [51]. However, in this study, during post-monsoon, $\mathrm{Fe} / \mathrm{As}$ ratio was more than 25 in raw water and the As removal efficiency was more than $80 \%$. Apparently, when Fe/As ratio is lower than 20, As removal efficiencies are also lower than $70 \%$.

\subsection{Efficiency of AIRPs in Terms of Health Risk Assessment}

The noncarcinogenic risk in terms of HQs of As and Fe consumption from raw and treated water was estimated for adults and children in the study area. If the value of HQ is less than unity, the exposed population is assumed to experience no adverse health effects. On the contrary, if the HQ is greater than the unity, there is a potential health risk to the population [52]. The HQ for As is presented in Figure 7A and the results suggested that in treated water, the HQ values for most of the AIRPs are higher than the threshold value indicating there is still potential health risk to the population. The mean HQ of raw and treated water for adult was $15.9 \pm 10.1$ and $3.4 \pm 3.1$, respectively, in pre-monsoon and these values were $13.1 \pm 7.7$ and $2.2 \pm 2.2$, respectively, in post-monsoon. Similarly, the mean HQ of raw and treated water for children was $41.8 \pm 26.1$ and $8.8 \pm 8.3$, respectively, in pre-monsoon and these values were $34.5 \pm 20.1$ and $5.80 \pm 5.7$, respectively, in postmonsoon (Table S3). Nevertheless, some AIRPs, namely G-1, G-2, G-3, G-6, M-2, M-3, and M-4 showed that HQ values for adults and G-3, G-6, and M-2 for children in treated water were less than one during pre-monsoon and post-monsoon, respectively (Figure 7A). The HQ values were several-fold higher for children than adults in both pre-monsoon and post-monsoon, which confirmed that children were at higher risk (Figure 7A). The descriptive summary of HQ of As and Fe in regard to mean, median, standard deviation, and percentiles are tabulated in Tables S3 and S4.

In addition to As, $\mathrm{HQ}$ of Fe was also calculated which is presented in Figure 7B. It is observed that AIRP treated water has HQ values less than 1 for adults and children during pre- and post-monsoon. Similarly, HQ of Fe in raw water for adults during preand post-monsoon is lower than 1, indicating no potential health risks to the population. However, for children, the $\mathrm{HQ}$ of $\mathrm{Fe}$ in raw water during both periods showed relatively 
higher values and in only one sample (M-9) the HQs was equal to the threshold value of 1 (Figure 7B).
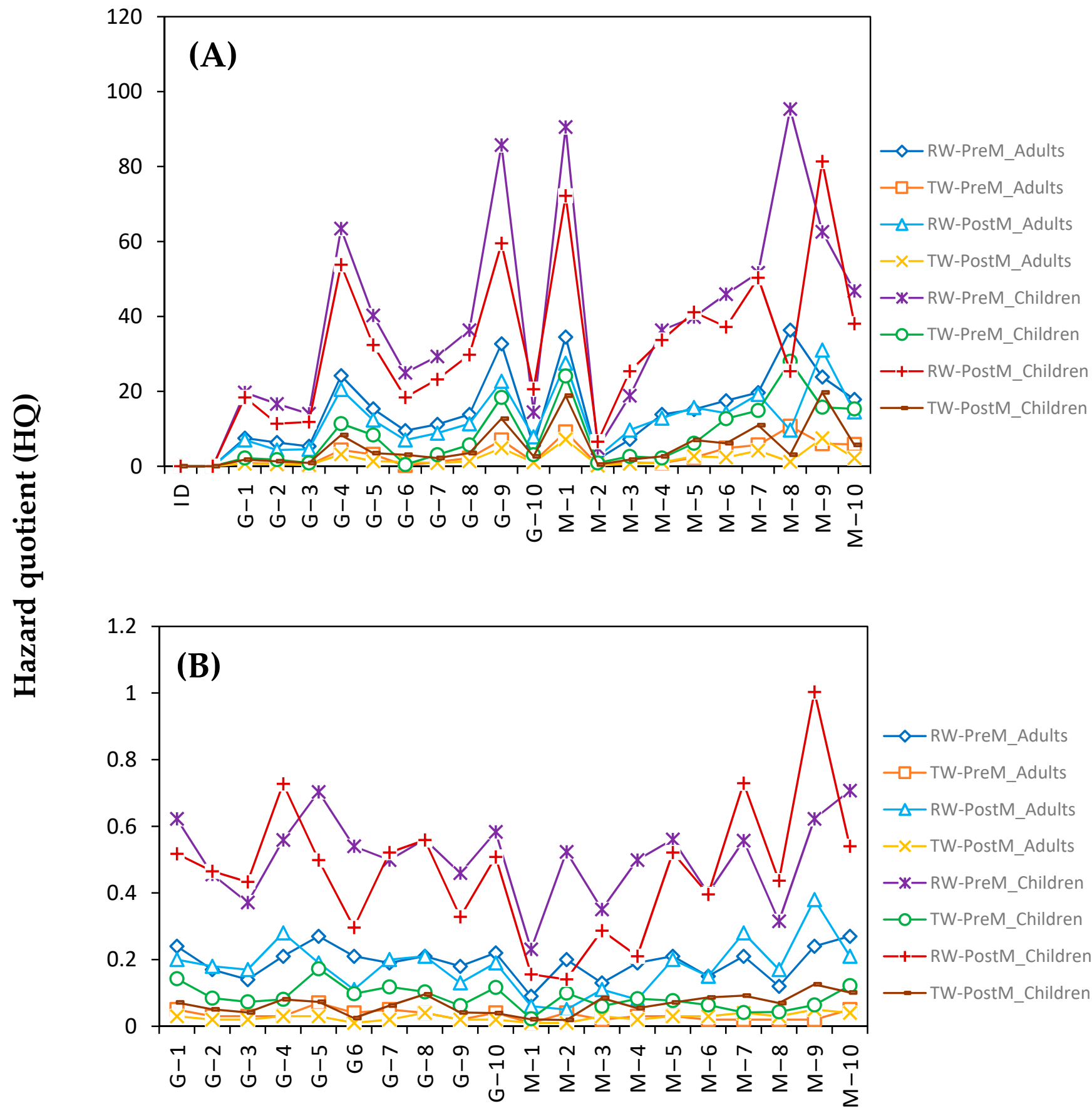

\section{Samples ID}

Figure 7. Hazard quotient (HQ) of As (A) and Fe (B); in raw and treated water by AIRPs for adults and children duringmonsoon and post-monsoon in rural areas of Bangladesh (RW-PreM, TW-PreM, RW-PostM, and TW-PostM refer to raw water pre-monsoon, treated water pre-monsoon, raw water post-monsoon, and treated water post-monsoon, respectively).

The CR of As in raw and treated water for both adults and children during preand post-monsoon is presented in Figure 8. The threshold value for CR is $10^{-6}-10^{-4}$ 
provided by US EPA [46]. It was observed that almost at all AIRPs, the CR values of As in treated water for adults were higher than the upper limit of $10^{-4}$ except G-6 during pre-monsoon and M-2 during post-monsoon (Figure 8). The calculated mean value of CR in raw well water and AIRP treated water was 0.0072 and 0.0015 in pre-monsoon; and 0.0059 and 0.0001 in post-monsoon for adults (Table S5), whereas that for 0.0188 and 0.004 in pre-monsoon and 0.015 and 0.0031 in post-monsoon for children, respectively (Table S5). Results demonstrated that all of the AIRPs, the CR of As in treated water were higher than the upper limit of $10^{-4}$, indicating both children and adults were at greater cancer risk in the study area. No variation of CR for both adults and children was noticed during pre- and post-monsoon. The descriptive summary CR in terms of mean, median, standard deviation, and percentiles (25th, 50th, and 75th) are described in Table S5.

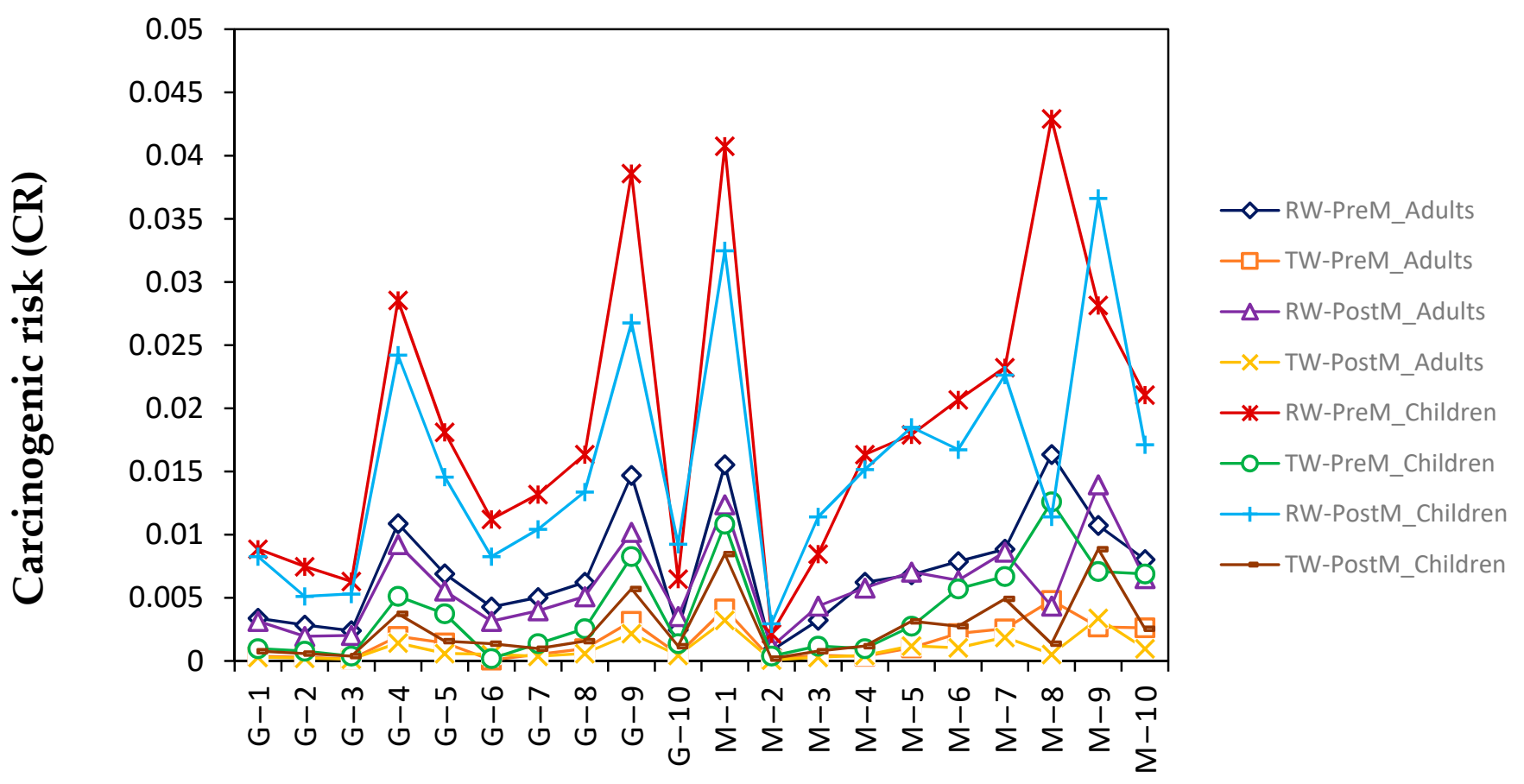

Samples

Figure 8. Carcinogenic risk (CR) of As in raw and treated water by AIRPs for adults and children during pre-monsoon and post-monsoon in rural areas of Bangladesh (RW-PreM, TW-PreM, RW-PostM, and TW-PostM refer to raw water pre-monsoon, treated water pre-monsoon, raw water post-monsoon, and treated water post-monsoon, respectively).

\section{Conclusions}

AIRP technology can be used for removing As and Fe in a low-income country to reduce exposure to As and risks associated with its consumption through drinking water. During pre-monsoon, As removal efficiencies ranged from $67 \%$ to $98 \%$ and during post-monsoon, it ranged between $74 \%$ and $93 \%$. The results revealed there was a greater efficiency of AIRPs in the post-monsoon season. Additionally, during pre-monsoon, after treatment with the AIRPs, only two samples exceeded the Bangladesh drinking water standard limit of $50 \mu \mathrm{g} \mathrm{L}^{-1}$, and 11 samples out of 20 were unable to remove anything below the WHO provisional guideline limit of $10 \mu \mathrm{g} \mathrm{L}^{-1}$. On the other hand, during postmonsoon, after treatment with AIRPs, none of the samples exceeded the standard limit of Bangladesh. However, eight of them exceeded the provisional guideline limit of WHO. The Fe removal efficiencies ranged between $75-93 \%$ and $71-92 \%$ during pre-monsoon and post-monsoon, respectively, which indicated no interseasonal variability on Fe removal 
efficiencies by AIRPs. During pre-monsoon and post-monsoon, after treatment with AIRPs, all water samples were below the Bangladesh standard limit of Fe.

The Pearson's correlation and PCA analysis indicated that As removal efficiency is dependent on $\mathrm{Fe} / \mathrm{As}$ ratio and As concentration in raw water, whereas Fe removal efficiency is independent of them. The HQ and CR of As in treated water indicated potential human health risks of adults and children in the study area due to the consumption of water. In contrast to As, HQ of Fe in treated water was lower than the threshold limit of 1 for both adults and children during pre-monsoon and post-monsoon, indicating no noncancer risks are associated with $\mathrm{Fe}$ in treated water. Comparing children with adults found that children are more susceptible to lifetime noncarcinogenic and carcinogenic health risks. Seasonal variation does not affect the $\mathrm{HQ}$ and $\mathrm{CR}$ values primarily. The As and Fe removal efficiencies need to be enhanced by modifications (such as design, filtering material used, etc.) of AIRP to ensure potable water. Future studies should also consider the naturally occurring manganese levels present in groundwater and how $\mathrm{Mn} / \mathrm{As}$ ratio contributes to the removal efficiencies of As.

Supplementary Materials: The following are available online at https:/ /www.mdpi.com/2073-444 $1 / 13 / 3 / 354 / \mathrm{s} 1$, Table S1: The concentration of As and $\mathrm{Fe}\left(\mu \mathrm{g} \mathrm{L}^{-1}\right)$ in raw water and treated water by AIRP from rural areas in Bangladesh, Table S2: The removal efficiency of As and Fe by AIRP from rural areas in Bangladesh in pre-monsoon and post-monsoon, Table S3: Summary of Hazard quotient $(\mathrm{HQ})$ of As in raw and treated water by AIRPs for adults and children during-monsoon and post-monsoon in rural areas of Bangladesh, Table S4: Summary of Hazard quotient (HQ) of Fe in raw and treated water by AIRPs for adults and children during-monsoon and post-monsoon in rural areas of Bangladesh, Table S5: Summary of Carcinogenic risk (CR) of As in raw and treated water by AIRPs for adults and children during pre-monsoon and post-monsoon in rural areas of Bangladesh.

Author Contributions: Conceptual: M.A.R., S.K. and M.M.R.; Methodology: M.A.R., S.K. and A.S.M.F.B.; Sampling: M.A.R. and S.K.; Analysis: M.A.R. and A.S.; writing-original draft preparation: M.A.R.; writing-review and editing: M.A.R., S.K., A.S.M.F.B., A.S. and M.M.R. All authors have read and agreed to the published version of the manuscript.

Funding: This research received no external funding.

Institutional Review Board Statement: Not applicable.

Informed Consent Statement: Not applicable.

Data Availability Statement: (DPHE), Zonal Laboratory, Khulna, Bangladesh for providing the metal testing facilities.

Acknowledgments: The authors are thankful to the Department of Public Health Engineering.

Conflicts of Interest: The authors declare that there is no conflict of interest.

\section{References}

1. Naidu, R.; Smith, E.; Owens, G.; Bhattacharya, P. Managing Arsenic in the Environment: From Soil to Human Health; CSIRO Publishing: Clayton, VIC, Australia, 2006.

2. Mandal, B.K.; Suzuki, K.T. Arsenic round the world: A review. Talanta 2002, 58, 201-235. [CrossRef]

3. IARC (International Agency for Research on Cancer); Working Group on the Evaluation of Carcinogenic Risks to Humans. Chemical Agents and Related Occupations; IARC Monographs on the Evaluation of Carcinogenic Risks to Humans; IARC: Lyon, France, 2012; Volume 100 F, p. 9.

4. Rahman, M.M.; Naidu, R.; Bhattacharya, P. Arsenic contamination in groundwater in the Southeast Asia region. Environ. Geochem. Health 2009, 31, 9-21. [CrossRef] [PubMed]

5. Chakraborti, D.; Rahman, M.M.; Das, B.; Murrill, M.; Dey, S.; Mukherjee, S.C.; Dhar, R.K.; Biswas, B.K.; Chowdhury, U.K.; Roy, S. Status of groundwater arsenic contamination in Bangladesh: A 14-year study report. Water Res. 2010, 44, 5789-5802. [CrossRef] [PubMed]

6. Fendorf, S.; Benner, S.G. Hydrology: Indo-Gangetic groundwater threat. Nat. Geosci. 2016, 9, 732-733. [CrossRef]

7. Rasheed, H.; Slack, R.; Kay, P. Human health risk assessment for arsenic: A critical review. Crit. Rev. Environ. Sci. Technol. 2016, 46, 1529-1583. [CrossRef] 
8. Stopelli, E.; Duyen, V.T.; Mai, T.T.; Trang, P.T.; Viet, P.H.; Lightfoot, A.; Kipfer, R.; Schneider, M.; Eiche, E.; Kontny, A. Spatial and temporal evolution of groundwater arsenic contamination in the Red River delta, Vietnam: Interplay of mobilisation and retardation processes. Sci. Total Environ. 2020, 717, 137143. [CrossRef]

9. Rahman, M.M.; Ng, J.C.; Naidu, R. Chronic exposure of arsenic via drinking water and its adverse health impacts on humans. Environ. Geochem. Health 2009, 31, 189-200. [CrossRef]

10. Brennan, R.; McBean, E. A performance assessment of arsenic-iron removal plants in the Manikganj District of Bangladesh. J. Water Health 2011, 9, 317-329. [CrossRef]

11. Goldhaber, S.B. Trace element risk assessment: Essentiality vs. toxicity. Regul. Toxicol. Pharmacol. 2003, 38, 232-242. [CrossRef]

12. WHO. Guidelines for Drinking Water Quality, 4th ed.; World Health Organization: Geneva, Switzerland, 2011.

13. ECR. The Environment Conservation Rules, 1997; Department of Environment \& Forest Ministry: Dhaka, Bangladesh, 1997; pp. 206-207.

14. Annaduzzaman, M.; Rietveld, L.C.; Hoque, B.A.; Bari, M.N.; van Halem, D. Arsenic removal from iron-containing groundwater by delayed aeration in dual-media sand filters. J. Hazard. Mater. 2020, 124823. in press.

15. Berg, M.; Luzi, S.; Trang, P.T.K.; Viet, P.H.; Giger, W.; Stüben, D. Arsenic removal from groundwater by household sand filters: Comparative field study, model calculations, and health benefits. Environ. Sci. Technol. 2006, 40, 5567-5573. [CrossRef] [PubMed]

16. Pham, T.D.; Pham, T.T.; Phan, M.N.; Ngo, T.M.V.; Vu, C.M. Adsorption characteristics of anionic surfactant onto laterite soil with differently charged surfaces and application for cationic dye removal. J. Mol. Liq. 2020, 301, 112456. [CrossRef]

17. Dao, T.-H.; Vu, T.-Q.-M.; Nguyen, N.-T.; Pham, T.-T.; Nguyen, T.-L.; Yusa, S.-I.; Pham, T.-D. Adsorption Characteristics of Synthesized Polyelectrolytes onto Alumina Nanoparticles and their Application in Antibiotic Removal. Langmuir 2020, 36, 13001-13011. [CrossRef] [PubMed]

18. Pham, T.D.; Tran, T.T.; Pham, T.T.; Dao, T.H.; Le, T.S. Adsorption characteristics of molecular oxytetracycline onto alumina particles: The role of surface modification with an anionic surfactant. J. Mol. Liq. 2019, 287, 110900. [CrossRef]

19. Wang, J.S.; Wai, C.M. Arsenic in drinking water-a global environmental problem. J. Chem. Educ. 2004, 81, 207. [CrossRef]

20. Callegari, A.; Ferronato, N.; Rada, E.C.; Capodaglio, A.G.; Torretta, V. Assessment of arsenic removal efficiency by an iron oxide-coated sand filter process. Environ. Sci. Pollut. Res. 2018, 25, 26135-26143. [CrossRef]

21. Kundu, D.K.; Gupta, A.; Mol, A.P.; Nasreen, M. Understanding social acceptability of arsenic-safe technologies in rural Bangladesh: A user-oriented analysis. Water Policy 2016, 18, 318-334. [CrossRef]

22. Hoque, B.A.; Yamaura, S.; Sakai, A.; Khanam, S.; Karim, M.; Hoque, Y.; Hossain, S.; Islam, S.; Hossain, O. Arsenic mitigation for water supply in Bangladesh: Appropriate technological and policy perspectives. Water Qual. Res. J. 2006, 41, 226-234. [CrossRef]

23. Singh, S.K. An analysis of the cost-effectiveness of arsenic mitigation technologies: Implications for public policy. International J. Sustain. Built Environ. 2017, 6, 522-535. [CrossRef]

24. Sorensen, I.M.; McBean, E.A. Beyond appropriate technology: Social considerations for the sustainable use of arsenic-iron removal plants in rural Bangladesh. Technol. Soc. 2015, 41, 1-9. [CrossRef]

25. Sharma, A.K.; Sorlini, S.; Crotti, B.M.; Collivignarelli, M.C.; Tjell, J.C.; Abbà, A. Enhancing arsenic removal from groundwater at household level with naturally occurring iron. Revista Ambiente Água 2016, 11, 486-498. [CrossRef]

26. Gude, J.; Rietveld, L.; van Halem, D. As (III) removal in rapid filters: Effect of pH, Fe (II)/Fe (III), filtration velocity and media size. Water Res. 2018, 147, 342-349. [CrossRef] [PubMed]

27. Holm, T.R.; Wilson, S.D. Chemical Oxidation for Arsenic Removal; TR06-05; MTAC Publication: Champaign, IL, USA, 2006.

28. Roberts, L.C.; Hug, S.J.; Ruettimann, T.; Billah, M.M.; Khan, A.W.; Rahman, M.T. Arsenic removal with iron (II) and iron (III) in waters with high silicate and phosphate concentrations. Environ. Sci. Technol. 2004, 38, 307-315. [CrossRef] [PubMed]

29. Mueller, B.; Hug, S.J. Climatic variations and de-coupling between arsenic and iron in arsenic contaminated ground water in the lowlands of Nepal. Chemosphere 2018, 210, 347-358. [CrossRef]

30. Berg, M.; Trang, P.T.K.; Stengel, C.; Buschmann, J.; Viet, P.H.; Van Dan, N.; Giger, W.; Stüben, D. Hydrological and sedimentary controls leading to arsenic contamination of groundwater in the Hanoi area, Vietnam: The impact of iron-arsenic ratios, peat, river bank deposits, and excessive groundwater abstraction. Chem. Geol. 2008, 249, 91-112. [CrossRef]

31. Ahmed, F.; Bibi, M.H.; Ishiga, H.; Fukushima, T.; Maruoka, T. Geochemical study of arsenic and other trace elements in groundwater and sediments of the Old Brahmaputra River Plain, Bangladesh. Environ. Earth Sci. 2010, 60, 1303-1316. [CrossRef]

32. Rahman, M.M.; Dong, Z.; Naidu, R. Concentrations of arsenic and other elements in groundwater of Bangladesh and West Bengal, India: Potential cancer risk. Chemosphere 2015, 139, 54-64. [CrossRef]

33. Van Geen, A.; Ahmed, K.; Seddique, A.; Shamsudduha, M. Community Wells to Mitigate the Arsenic Crisis in Bangladesh. Bull. World Health Organ. 2003, 81, 632-638.

34. Van Geen, A.; Ahsan, H.; Horneman, A.H.; Dhar, R.K.; Zheng, Y.; Hussain, I.; Ahmed, K.M.; Gelman, A.; Stute, M.; Simpson, H.J. Promotion of well-switching to mitigate the current arsenic crisis in Bangladesh. Bull. World Health Organ. $2002,80,732-737$.

35. Chakraborti, D.; Basu, G.K.; Biswas, B.K.; Chowdhury, U.K.; Rahman, M.M.; Paul, K.; Chowdhury, T.R.; Chanda, C.R.; Lodh, D.; Ray, S.L. Characterization of arsenic bearing sediments in Gangetic delta of West Bengal-India. In Arsenic Exposure and Health Effects; Elsevier Science: New York, NY, USA, 2001; pp. 27-52.

36. Farooq, S.; Chandrasekharam, D.; Norra, S.; Berner, Z.; Eiche, E.; Thambidurai, P.; Stüben, D. Temporal variations in arsenic concentration in the groundwater of Murshidabad District, West Bengal, India. Environ. Earth Sci. 2011, 62, 223-232. [CrossRef]

37. Ravenscroft, P.; Howarth, R.J.; McArthur, J.M. Comment on “Limited temporal variability of arsenic concentrations in 20 wells monitored for 3 Years in Araihazar, Bangladesh". Environ. Sci. Technol. 2006, 40, 1716-1717. [CrossRef] [PubMed] 
38. Sengupta, M.K.; Mukherjee, A.; Ahamed, S.; Hossain, M.A.; Das, B.; Nayak, B.; Chakraborti, D.; Goswami, A.B. Comment on "Limited Temporal Variability of Arsenic Concentrations in 20 Wells Monitored for 3 Years in Araihazar, Bangladesh". Environ. Sci. Technol. 2006, 40, 1714-1715. [CrossRef] [PubMed]

39. Kumar, M.; Kumar, P.; Ramanathan, A.; Bhattacharya, P.; Thunvik, R.; Singh, U.K.; Tsujimura, M.; Sracek, O. Arsenic enrichment in groundwater in the middle Gangetic Plain of Ghazipur District in Uttar Pradesh, India. J. Geochem. Explor. 2010, 105, 83-94. [CrossRef]

40. Hossain, M.A.; Mukharjee, A.; Sengupta, M.K.; Ahamed, S.; Das, B.; Nayak, B.; Pal, A.; Rahman, M.M.; Chakraborti, D. Million dollar arsenic removal plants in West Bengal, India: Useful or not? Water Qual. Res. J. 2006, 41, 216-225. [CrossRef]

41. Sorensen, I.M.; McBean, E.A.; Rahman, M. Retrofitting arsenic-iron removal plants in rural Bangladesh for performance enhancement. J. Water Sanit. Hyg. Dev. 2014, 4, 400-409. [CrossRef]

42. APHA. American Public Health Association. Standard Methods for the Examination of Water and Wastewater; American Public Health Association: Denver, CO, USA, 2012.

43. Rahman, M.A.; Kumar, S.; Mohana, A.A.; Islam, R.; Hashem, M.A.; Chuanxiu, L. Coliform Bacteria and trace metals in drinking water, southwest Bangladesh: Multivariate and human health risk assessment. Int. J. Environ. Res. 2019, 13, 395-408. [CrossRef]

44. US-EPA (United States-Environmental Protection Agency). Regional Screening Levels (RSLs)-Equations; US-EPA: Washington, DC, USA, 2019. Available online: https:/ / www.epa.gov/risk/regional-screening-levels-rsls-equations (accessed on 26 August 2019).

45. Hossain, M.A.; Rahman, M.M.; Murrill, M.; Das, B.; Roy, B.; Dey, S.; Maity, D.; Chakraborti, D. Water consumption patterns and factors contributing to water consumption in arsenic affected population of rural West Bengal, India. Sci. Total Environ. 2013, 463, 1217-1224. [CrossRef]

46. US-EPA (United States-Environmental Protection Agency). Regional Screening Levels (RSLs)-Generic Tables, Tables as of Regional Screening Level (RSL) Summary Table (TR=1E-06, HQ=1); US-EPA: Washington, DC, USA, 2019.

47. Rodriguez, R.; Ramos, J.; Armienta, A. Groundwater arsenic variations: The role of local geology and rainfall. Appl. Geochem. 2004, 19, 245-250. [CrossRef]

48. Ghosh, G.C.; Khan, M.J.H.; Chakraborty, T.K.; Zaman, S.; Kabir, A.E.; Tanaka, H. Human health risk assessment of elevated and variable iron and manganese intake with arsenic-safe groundwater in Jashore, Bangladesh. Sci. Rep. 2020, 10, 1-9. [CrossRef]

49. Rahman, M.H.; Rahman, M.Z. Performance of arsenic and iron removal plants in Bangladesh. In Proceedings of the 30th WEDC International Conference, Vientiane, Laos, 25-29 October 2004.

50. Ahmed, F. Development of Community Based Arsenic E Iron Removal Unit for Rural Water Supply System; ITN-Bangladesh, Centre for Water Supply and Waste Management, BUET: Dkhaka, Bangladesh, 2005; Volume 6.

51. US-EPA (United States-Environmental Protection Agency). Oxidation filtration (iron removal). In Arsenic Virtual Trade Show; US-EPA: Washington, DC, USA, 2019. Available online: https:/ / cfpub.epa.gov/safewater/arsenic/arsenictradeshow/arsenic. cfm?action=Oxidation (accessed on 26 August 2019).

52. Islam, R.; Kumar, S.; Rahman, A.; Karmoker, J.; Ali, S.; Islam, S.; Islam, M.S. Trace metals concentration in vegetables of a sub-urban industrial area of Bangladesh and associated health risk assessment. AIMS Environ. Sci. 2018, 5, 130-142. [CrossRef] 